\title{
Lealdade, ambivalência e rebeldia: as estratégias de relacionamento de Oswald de Andrade e Menotti del Picchia na construção de suas redes de sociabilidade 12
}

\author{
Loyalty, ambivalence and rebelliousness: the relationship \\ strategies of Oswald de Andrade and Menotti del Picchia in the \\ construction of their sociability networks
}

Vanessa Konopczyk Amaral Ribeiro ${ }^{(i)}$

(i) Universidade Estadual de Campinas - Unicamp, Campinas, SP, Brasil. https://orcid.org/0000-00031405-9639,konopczyk@hotmail.com.

\begin{abstract}
Resumo:
O objetivo do artigo é investigar como são construídas as redes de sociabilidade a partir da experiência escolar e a importância da escola como dispositivo de ascensão social. Para tanto, identificam-se as diferenças nas estratégias de relacionamento desenvolvidas por Oswald de Andrade e Menotti del Picchia, dois dos autores fundamentais do modernismo paulista, na construção de suas redes de sociabilidade, a partir da análise de suas trajetórias escolares e relações familiares, apontadas pelos autores em suas autobiografias. A partir das concepções de Sirinelli, investigaramse as formas como os autores perceberam a própria experiência escolar, vista como catalisadora das relações de redes de sociabilidade que possibilitaram sua ascensão social, no caso de Menotti, filho de imigrantes, ou manifestamente um espaço de manutenção de poder, caso de Oswald, de família rica e influente. A análise dos percursos escolares evidencia a forma como cada um agiu antes de seu encontro no movimento modernista e permite compreender como seus comportamentos e práticas, a partir de seus lugares sociais e demais experiências formativas, tiveram peso nas escolhas sociopolíticas feitas por ambos, revelando estratégias, pressões e relações de força política e religiosa na busca pela circunscrição de seus próprios espaços, sobretudo com o advento da Semana de Arte Moderna.

Palavras-chave: literatura modernista, autobiografias, escolarização, redes de sociabilidade
\end{abstract}

\footnotetext{
${ }^{1}$ Editor responsável: Alexandre Filordi de Carvalho - afilordi@gmail.com. https://orcid.org/0000-0003-4510-9440.

${ }^{2}$ Normalização, preparação e revisão textual: Douglas Mattos (Tikinet) - revisao@tikinet.com.br
} 


\begin{abstract}
:
The objective of this article is to investigate how sociability networks are built from school experience, and the importance of school as a device for social ascension. To that end, we identify the relationship strategies developed by Oswald de Andrade and Menotti del Picchia, two of the fundamental authors of São Paulo's modernism, in the establishment of their sociability networks based on the analysis of their school trajectories and family relations, as pointed out by their autobiographies. From the concepts of Sirinelli, we investigated the ways in which the authors perceived their own school experience as, a catalyst for the networking that enabled their social ascension, in the case of Menotti, a son of humble immigrants, or manifestly a space of maintenance of power in Oswald's case who was from a rich and influential family. The analysis of the school paths shows how each one acted before their meeting in the modernist movement and allows to understand how their behaviors and practices, had weight in the social and political choices made by both, from their social places and other formative experiences, revealing strategies, pressures and relations of political and religious strength in the search for conquering their own spaces, especially with the advent of the Modern Art Week.
\end{abstract}

Keywords: modernist literature, autobiographies, schooling, sociability networks

O artigo parte de tese de doutorado concluída e trata de questões referentes à trajetória escolar e biográfica de dois dos autores fundamentais do modernismo paulista, Menotti del Picchia e Oswald de Andrade, segundo Martins (2002). A opção de recorte pelos dois autores se deu pelo fato de ambos terem escrito suas autobiografias no universo dos autores compreendidos pela pesquisa. Além disso, a distinção é pertinente por conta da diferença dos lugares sociais de Oswald de Andrade e Menotti del Picchia, que operaram forte impacto em suas decisões, não apenas no movimento literário, mas principalmente no que se referiu às suas escolhas políticas, por meio da construção de suas redes de sociabilidade, conforme Sirinelli (2003).

A verificação de como Menotti del Picchia e Oswald de Andrade construíram suas redes de sociabilidade parte da premissa do comportamento aprendido entre pares, que, no caso dos autores modernistas, foi forjada desde os bancos escolares, o que equivale a dizer que o encontro deles no interior da Semana de Arte Moderna não teria sido possível sem o prévio estabelecimento das redes que constituíram suas bases depois de adultos.

Tanto Picchia quanto Andrade alcançaram lugares próprios e demarcados no interior do movimento modernista. Suas estratégias de relacionamento com o estrato dominante foram 


\section{pro.posıções}

$e$-ISSN 1980-6248

http://dx.doi.org/10.1590/1980-6248-2019-0029

distintas e bastante particulares, em grande parte determinadas por suas experiências familiares e seus primeiros anos de escolarização.

O mero levantamento biográfico dos dois modernistas ou o estudo isolado de suas trajetórias escolares não seria suficiente para abranger as experiências de sociabilidade de ambos. Por isso, parte-se do pressuposto de que levantar seus percursos escolares mostra como operaram relações a partir da escola, elemento-chave na formação das redes de sociabilidade que possibilita situá-los no universo em que viveram e compreender as escolhas políticas que fizeram.

A partir das memórias de Menotti del Picchia, narradas em $A$ longa viagem, e de Oswald de Andrade, registradas em Um homem sem profissão, observou-se a ideia de promover uma discussão acerca de personalidades que guardaram diferenças, mas que indicam também muitas convergências, sobretudo no que se refere à escolarização de ambos. Além de fazerem parte do movimento que ousou renovar e questionar as letras em São Paulo, os autores viabilizaram escolhas que invariavelmente tiveram como ponto de origem suas sociabilidades, desenvolvidas a partir da escola.

A distinção dos autores a partir do estudo de Miceli (2001) sinaliza como se comportaram diante da escolarização que receberam, realizada tanto em escolas públicas como privadas na capital e no interior. Captando nuances de suas formações e comportamentos, apreende-se como se deu o estabelecimento das redes de sociabilidade que posteriormente promoveram seu encontro e atuação no movimento modernista, além de garantir sua presença nos espaços públicos e privados reservados aos estratos sociais mais elevados.

Além dos percursos escolares, identificou-se elementos da formação de Oswald de Andrade e Menotti del Picchia a partir de suas relações familiares e sociais, tecendo uma aproximação entre essas experiências e os posicionamentos políticos que os autores assumiram durante a vida, demonstrando que a forma de educação recebida no interior da família orientou o pensamento político e as ambiguidades que se concretizaram a partir do desenvolvimento das redes de sociabilidade.

A ideia é de que suas experiências de escolarização se relacionaram ao trânsito que empreenderam nas altas esferas da vida pública paulista, além de terem funcionado como catalisadoras na formação das redes que culminaram na realização da Semana de Arte Moderna, em 1922 


\section{Oswald de Andrade, a representação da rebeldia sem causa}

Oswald de Andrade era o que Miceli (2001) definiu por dândi, por conta de seu estilo de vida exagerado de quem quer estar sempre em evidência. Rico, filho único e mimado, neto de desembargador, nasceu em 1890 na capital paulista. Seu pai foi vereador na cidade de São Paulo e fez fortuna com a venda de terrenos e corretagem de imóveis. O menino Oswald passou por vários colégios até chegar à Faculdade de Direito de São Paulo, instituição que contava com enorme prestígio social.

Suas memórias foram narradas a pedido de Antonio Candido, que o estimulou a escrever e também o prefaciou em Um homem sem profissão. No prefácio da edição de 1954, Candido indica que nada poderia ser dito sobre Oswald, pois ele teria feito da própria vida romance e poesia. Dono de uma vida rica e repleta de simbolismos, suas memórias revelam várias facetas de sua personalidade, ora endurecida, ora rebelde, mas também leve, prazerosa, despreocupada e original.

Oswald recebeu esmerada educação religiosa. Em suas memórias, narrou que a mãe, figura especial em sua vida, mantinha em casa várias imagens de santos, assistia às missas na Igreja da Consolação e participava de romarias e procissões, nas quais o vestia de anjo. Da religiosidade materna, Oswald herdou uma insistente superstição, que, talvez por conta de sua rebeldia, não o deixava acatar como natural o que lhe era ensinado. Apesar da educação católica, Oswald de Andrade não precisava do apoio e da proteção de autoridades eclesiásticas para garantir oportunidades já recomendadas naturalmente, por conta do capital social e financeiro amealhado por sua família.

Além de não precisar do acolhimento da Igreja, aos poucos Oswald de Andrade foi se revelando crítico dos costumes da boa educação religiosa e moral de seu tempo, deixando entrever os desconfortos que sentia diante das impossibilidades que a família e a Igreja queriam lhe impor, como revela: "ser bem educado era fugir da vida. As mulheres não podiam sequer revelar a sexualidade natural que todas têm. Eram logo putas" (Andrade, 1976, p. 56).

O estilo de vida boêmio de Oswald se aproxima do que Bourdieu (1996) identificou sobre a vida artística francesa desde fins do XVIII, quando os intelectuais fizeram da boemia uma arte de viver, se utilizando das canções, bebida, trocadilhos e fantasias que serviam para criticar e colorir as rotinas tediosas da vida burguesa. Entretanto, seu afastamento da Igreja e as 


\section{pro.posıções}

$e$-ISSN 1980-6248

http://dx.doi.org/10.1590/1980-6248-2019-0029

provocações sistemáticas aos costumes de seu estrato social não lhe ficaram impunes e estão na origem dos ataques supersticiosos e do comportamento ambivalente que oscilava entre a culpa e a rebeldia, que o acompanhou por toda sua vida.

Sua infância e juventude se entrelaçaram com a transformação da acanhada capital paulista em metrópole de vida econômica vigorosa e rica de signos sociais que pouco a pouco foram sendo identificados com as esferas privilegiadas, como os automóveis, signos da modernidade e agilidade comumente associadas aos anos de 1920. A cidade de São Paulo experimentada por Oswald de Andrade buscava a modernidade típica e inerente ao período.

Como moço rico, Oswald pôde empreender viagens à Europa e dar-se o luxo de possuir alguns dos símbolos da modernidade, como um automóvel. Boaventura (1995) conta que ele foi um dos primeiros modernistas a ter automóvel, um carro inglês. Seu estilo de vida indicava principalmente uma filosofia de vida, como afirmou Sevcenko (1992): “ser jovem, desportista, vestir-se e saber dançar os ritmos da moda é ser 'moderno', a consagração máxima” (p. 34).

Ser moderno significava estar sempre à frente de si mesmo, numa eterna transgressão. No caso de Oswald de Andrade, a transgressão o acompanhou por toda a sua vida e fez parte de suas escolhas e vontades, percebidas desde os primeiros anos escolares até seus arranjos e opções políticas.

Contrariando os anseios de seu estrato social, não queria cursar a Faculdade de Direito. Feliz com a possibilidade de enveredar pelo jornalismo, foi admitido, por influência do pai, na redação do jornal Diário Popular no início de 1909, mas se rendeu às pressões familiares, sobretudo da mãe, e se matriculou na Faculdade de Direito de São Paulo. Tentou convencer a mãe da inutilidade do curso, mas d. Inês, irredutível, acreditava que o diploma poderia ser-lhe útil e o fez prometer que se tornaria bacharel. A percepção dessa situação é crucial para entender as diferenças no comportamento de Oswald e Menotti, que empreendeu todos os esforços que pôde no sentido de alcançar a ascensão social por meio do curso de Direito.

\section{Menotti del Picchia, a representação da disponibilidade}

A autobiografia de Menotti del Picchia, A longa viagem, foi construída numa linha de orgulho pela própria trajetória. Organizada em dois volumes, Menotti, pragmático, fez de sua 


\section{pro.posıções}

$e$-ISSN 1980-6248

http://dx.doi.org/10.1590/1980-6248-2019-0029

narrativa um ato de escrita, tal como Hébrard (2001) assinala em relação às autobiografias dos autodidatas. O prefácio, escrito pelo próprio Menotti, opera na clara intenção de se dar a ver no tempo futuro, como o próprio autor afirma: "conto os episódios desta longa viagem para Vocês, meus netos, naturalmente interessados em saber por quais caminhos andou, no tempo, o vosso sangue" (Picchia, 1970, p. 2).

Menotti del Picchia afirma em sua autobiografia que foi um autodidata e que, com extrema dificuldade, guardava 10 mil réis mensais para comprar livros e aprender idiomas. Talvez por conta de sua origem humilde e imigrante, demonstrou em suas memórias a importância que deu à escolarização em sua trajetória, afirmando a importância das redes de relações que estabeleceu a partir dos lugares onde estudou. A relação com a cultura erudita surge em suas memórias como determinante em seu caminho como escritor, articulando-se com suas ambivalências.

Em 1892, Menotti del Picchia nasceu na capital paulista. Ao contrário de Oswald, filho único, Menotti era o caçula de uma família humilde, numerosa e imigrante, que não contou com os trunfos sociais e econômicos que resguardaram Oswald das dificuldades da vida. Miceli (2001) classifica a situação de Menotti como de primo pobre, identificando-o como autor que não pertencia à oligarquia e vinha do interior a fim de tentar sobreviver na capital paulista.

Apesar de nascido em São Paulo, Menotti del Picchia foi criado no interior. Seu pai, em razão do trabalho como pequeno empreiteiro, pintor e artista, levou toda a família para residir na cidade de Itapira. Menotti iniciou suas primeiras letras no Grupo Escolar do Arouche, na capital, mas foi a partir da formação no Grupo Escolar em Itapira que passou a construir suas relações.

Guardou, à semelhança de Oswald de Andrade, o assumido mimo que recebeu da mãe, além de uma sólida formação religiosa, que, no seu caso, para além da orientação espiritual, serviu principalmente como trunfo na construção de suas relações e possibilidades de escolarização. Vindo do interior para estudar na Faculdade de Direito de São Paulo, Menotti não usufruiu das transformações sociais e econômicas que fervilhavam na capital paulista.

Apesar de não ter contado com as vantagens e trunfos culturais que favoreceram a vida de Oswald, lentamente construiu seu repertório com o apoio de instituições importantes na oligarquia paulista, especialmente o Partido Republicano Paulista (PRP) e a Igreja Católica. A carreira e vida política de Menotti del Picchia foi claramente construída em sua relação com a 


\section{pro.posıções}

$e$-ISSN 1980-6248

http://dx.doi.org/10.1590/1980-6248-2019-0029

Igreja, sobretudo na figura do bispo D. João Batista Nery, responsável direto por sua escolarização desde o ginásio até o ingresso na Faculdade de Direito de São Paulo, como afirmou em sua autobiografia.

Vista como uma forma de obter vantagens sociais e culturais, a aproximação com a Igreja foi algo comum nas estratégias de sobrevivência dos primos pobres, que, por conta da fragilidade de sua situação na oligarquia, buscavam outras formas de proteção, como o ingresso no seminário, por exemplo, que os ajudava a se proteger do rebaixamento social, além de favorecer o acúmulo de capital cultural, segundo Miceli (2001).

Sem nada a perder na busca por um lugar no interior da oligarquia, a posição exercida por Menotti del Picchia é justificada, de acordo com as representações identificadas por Miceli (2001). Jovem, sem recursos e vindo do interior, buscou com determinação alcançar os lugares que atingiu dentro do movimento modernista.

Menotti, apesar de não ter sido seminarista, foi coroinha e recebeu educação católica desde o berço, destacando em $A$ longa viagem o papel fundamental que teve em sua trajetória o bispo D. João Batista Nery, que lhe ofereceu a oportunidade de estudar no Ginásio Diocesano São José, reservado aos filhos da elite paulista e localizado na cidade mineira de Pouso Alegre.

Sua posição frágil revelou logo o lado que ele escolheria para conquistar seu espaço. Munido da necessária sutileza que caracteriza o jogo político, desde criança no Ginásio Diocesano de Pouso Alegre, adotou uma postura de protegido, agindo com antecipação e colocando sempre disponíveis seus talentos e habilidades de escultor e artista, herdados do pai. Fosse por receio de desapontar a família e o bispo protetor ou por vislumbrar possibilidades de ascensão social, Menotti agiu recorrentemente em prol do serviço ativo e da disponibilidade, o que, segundo ele, aos poucos the garantiu o reconhecimento buscado.

Sagaz, aos poucos adotou uma postura de integração com o grupo modernista de que fez parte, a despeito das posições conservadoras que assumiu no interior do movimento. Apesar de sua origem, incorporou hábitos comuns a Oswald de Andrade. Em São Paulo, já adulto, Menotti praticou esportes e passou noites na garçonnière de Oswald. Em suas memórias, Menotti, já consagrado escritor e dono de sólida carreira política, lembrou com orgulho que, assim como Oswald, também teve um automóvel: "tudo que fôsse moderno e renovador nos atraía. Ambos, do grupo, fomos os únicos a motorizar-nos. Oswald no volante de uma importante 'Moon', carro inglês e eu num 'Buick', veículo americano, de série.” (Picchia, 1970, p. 68). 


\section{Redes de sociabilidade e escolarização, abrindo caminhos}

Tecer o estabelecimento das primeiras redes de sociabilidade dos autores a partir de seus percursos escolares liga-se às solidariedades de origem, idade e estudos, que constituem as bases das redes dos intelectuais adultos, segundo Sirinelli (2003). A despeito de seus lugares sociais distintos, o encontro entre Oswald de Andrade e Menotti del Picchia foi possível por conta da escolarização de Menotti, sem a qual eles não teriam se encontrado na capital paulista.

Nesse sentido, considera-se, pois, que a trajetória escolar dos autores funcionou como peça mestra para o estabelecimento das redes que posteriormente uniram as trajetórias profissionais e as opções literárias abraçadas por eles, não deixando dúvidas sobre escolhas futuras e comprovando o poder das relações sociais desenvolvidas a partir da escola.

Não obstante serem classificados dândis ou primos pobres, a experiência de escolarização de Menotti e Oswald os compreende numa trama maior, em relação. Sirinelli (2003) indica que o comportamento intelectual é aprendido na relação com os pares, variando de acordo com as épocas e os grupos estudados. Ao investigarmos as solidariedades de origem educacional de nossos autores, conseguimos traçar as bases de suas redes de sociabilidade em sua vida adulta e sobre as quais fundamentaram suas carreiras intelectuais e políticas.

A partir dos percursos, percebeu-se que tanto Oswald de Andrade quanto Menotti del Picchia operaram uma escolarização formal comum. Mesmo não tendo estudado nas mesmas escolas, o capital intelectual recebido por Menotti mostrou-se fundamental para o estabelecimento das redes significadas por Sirinelli (2003), pois o encontro deles se deu em torno da construção editorial. Oswald foi quem o procurou, por conta do sucesso alcançado com a publicação de Juca Mulato. Menotti afirmou em suas memórias que o encontro com Oswald originou num pacto para iniciarem a revisão da literatura que vinha sendo feita no Brasil, o que vem ao encontro do estabelecimento das redes que viabilizaram a Semana de Arte Moderna.

Nem mesmo as rupturas intelectuais ou artísticas que envolveram os autores desarmaram as redes tecidas por eles. Sirinelli (2003) assevera que mesmo as rivalidades têm papel decisivo para o entendimento de como se operam as relações entre os intelectuais. A despeito de eventualmente Menotti e Oswald terem optado por escolhas estéticas e políticas que os afastaram, permaneceram as discussões sobre o estabelecimento de um novo sistema de 


\section{pro.posıções}

$e$-ISSN 1980-6248

http://dx.doi.org/10.1590/1980-6248-2019-0029

relações estéticas e de aparelhamento e filiações políticas que só foram possíveis a partir de suas redes originais, tecidas a partir de sua escolarização.

\section{Trajetórias escolares}

A trajetória escolar de Menotti del Picchia teve início no Grupo Escolar do Largo do Arouche, quando a família ainda residia em São Paulo. Em sua autobiografia, ele conta que não gostava da escola e sofria de saudades da mãe, e relembra os maus tratos e a rudeza do professor, o qual, segundo Menotti, não o estimulava e tinha por hábito mandar alguns alunos embora antes do fim das aulas, causa de alívio para ele:

É claro que eu ia. Ia porque não gostava do professor, nem da escola, nem da malta de moleques que ali, no recreio, erguiam uma algazarra de motim. A saudade de mamãe me atormentava. Corria para casa. Não ficava na rua como os outros colegas que se desafiavam para partidas de gude ou de peteca. Outros jogavam botões, tendo então visto muitos irem para casa segurando as calças cujas casas dos botões não tinham moradores... (Picchia, 1970, p. 48)

Numa ocasião em que cochilou durante a aula, Menotti recorda que esse professor o atingiu com uma pancada de livros na cabeça, gritando: "Está dormindo, songamonga?" (Picchia, 1970, p. 49). Assustado, Menotti relatou o ocorrido ao pai, que reagiu à violência colocando o filho noutra escola: "tirou-me imediatamente da escola e me levou, aí já com meu irmão Liberal, para um colégio particular regido por uma filha de alemães maternal e gorda” (p. 49).

Não permaneceu por muito tempo na escola particular. Por conta do trabalho do pai, encarregado de remodelar a Igreja de Itapira, toda a família se mudou para a pequena cidade do interior paulista. Em Itapira, o menino Menotti foi matriculado no Grupo Escolar Julio de Mesquita. Ao contrário da experiência paulistana, gostou da escola e dos professores, a quem relembrou como dedicados aos alunos e dotados do que considerou como consciência didática:

Um deles - Miguel Cardim - creio que fôsse paisano da militança pedagógica pois desconfio que nem siquer era formado. Isso não o impediu de ser um excelente mestre. Sua escola tinha um tic de boemia, mas sua enérgica vigilância tirava um grande rendimento daquela garotada chucra que travava uma séria batalha com o alfabeto. Miguel Cardim, magro, tipo do mestre escola descrito por Raul Pompéia, com um pomo de Adão mobil e nervoso no pescoço de galofrade, era tido como o romântico do corpo docente. Ao lado dele havia o austero professor Sizino, a vivaz professora Carmela, o culto Cezar Martinez e, para mim, o mais profundo, Jacomo Stavale, que teve, sem saber, uma destinação fundamental para o estímulo do meu estro poético. Era um grupo entusiasta que comporia "A Falange Gloriosa" do saudoso irônico Godofredo Rangel. (Picchia, 1970, p. 55) 


\section{pro.posıções}

$e$-ISSN 1980-6248

http://dx.doi.org/10.1590/1980-6248-2019-0029

A segunda experiência de Menotti num Grupo Escolar, desta vez no interior, indicou que o menino gostava da escola e dos professores, exceto das aulas de matemática da professora Carmela, que ensinava as somas juntando os números numa pedra, desenhando um risco e ordenando aos alunos que efetuassem. Ele relembra com orgulho do Grupo Escolar, sobretudo pelo episódio em que o poeta Coelho Neto visitou a escola, convidado por professores para ser o paraninfo da "Festa das Árvores". Segundo descreve, o fato de um poeta consagrado como Coelho Neto ter aceitado o convite demonstrava o padrão intelectual da equipe que compunha o grupo.

Terminado o Grupo Escolar, o pai de Menotti decidiu enviar o filho a São Paulo, pois Itapira não contava com um ginásio que possibilitasse o prosseguimento dos estudos. Novamente a ausência da mãe marcou o menino, que não suportou esse distanciamento e voltou para Itapira: "eu não estava ainda sentimentalmente desmamado. Não podia passar sem mamãe" (Picchia, 1970, p. 69).

O colo materno durou pouco e o pai decidiu enviá-lo para Campinas, a fim de cursar o Ginásio Culto à Ciência. Em sua autobiografia, Menotti afirmou que o colégio era muito prestigiado porque seus professores estimulavam o raciocínio dos alunos ante a memorização. $\mathrm{Na}$ instituição campineira, reencontrou Coelho Neto, desta vez como professor.

Foi em Pouso Alegre, entretanto, pequena cidade localizada no sul de Minas Gerais, que o menino Menotti narrou ter desenvolvido seus talentos. Mais uma vez, por conta do trabalho errante do pai e da orientação religiosa da família, teve a oportunidade de estudar num dos melhores colégios da época, segundo mencionou em sua autobiografia.

A cidade mineira era conhecida pela importância do Ginásio Diocesano São José, idealizado para atender aos filhos de famílias de fazendeiros. O sr. Luigi, pai de Menotti, seguiu para Pouso Alegre a fim de trabalhar nas obras do prédio do Ginásio Diocesano São José, e sua proximidade com o bispo D. João Batista Nery logo trouxe o convite para que transferisse o filho para o Ginásio em Minas. Menotti admitiu que receou ficar ainda mais longe da mãe, mas foi assertivo ao indicar o Ginásio Diocesano São José como o local decisivo para o desenvolvimento de suas competências: 
Ali desabrochei na potencial plenitude das minhas tendências alargando, para mim, o grande Bispo, as veredas de múltiplas vocações que eu carregava em recalque. Dois homens foram decisivos na minha formação cultural e na minha carreira política: D. Nery e Carlos de Campos. (Picchia, 1970, p. 79)

O menino Menotti, que não gostava de matemática no Grupo Escolar de Itapira, ganhou uma medalha na disciplina no Ginásio Diocesano São José. Esse ginásio, que funcionava em regime de internato e contava com capela e quadras, teve um lugar especial garantido nas memórias de Menotti, além de ter ambientado seu conto O árbitro (1959). O corpo de professores, composto basicamente por padres, contava com alguns leigos, entre os quais os professores de alemão, português e literatura e o professor de desenho, ninguém menos que José, o irmão mais velho de Menotti, também trazido pelo bispo por conta da amizade com o pai.

No conto $O$ árbitro, Menotti se utiliza da forma ficcional para se referir à própria experiência no ginásio, descrevendo sua angústia de menino miúdo diante do frio intenso que fazia na cidade, da saudade da mãe e dos novos colegas, que roubavam goiabada e acusavam os outros meninos de tê-lo beliscado na fila. Para Menotti, esses colegas, depois de adultos, mantinham o mesmo comportamento: "grandes, roubam heranças e urdem trampolinagens e falam mal de todo o mundo" (Picchia, 1959, p. 18). Na ficção construída em O árbitro, em contraponto ao que registrou em $A$ longa viagem, seu livro de memórias, Menotti descreveu o ginásio oferecendo pistas da rotina escolar imposta pelos padres:

O colégio era um grande dado côr de ocre, com uma escadaria imponente. Perto, - um longo paralelepípedo vertical, truncado no alto em pirâmide - a Capela. Por trás, o riacho puro, que fornecia água higiênica para lavar o rosto e para o banho porque os vigilantes, por instinto de sábios naturistas, submetiam-nos a uma hidroterapia primitiva que enrijava o corpo com abluções geladas, entregando-nos depois à ginástica. Com uma saúde vigorosa, tínhamos uma alegria de pássaros. Cantávamos hinos e ladainhas e roía-nos o estômago uma fome de ogres. (Picchia, 1959, p. 16)

A fome intensa a que Menotti se referiu suportava a comida ruim servida no refeitório do ginásio. Ainda em $O$ árbitro, narrou as más condições da alimentação do internato, que recebia filhos de boa parte da elite paulista: "a comida era ruim, como a dos quartéis e dos seminários. O feijão tinha pedra, uns insetos de tromba, duros, como microscópicos elefantes pretos e cristalizados" (Picchia, 1959, p. 16). 


\section{pro.posıções}

$e$-ISSN 1980-6248

http://dx.doi.org/10.1590/1980-6248-2019-0029

As contradições demarcadas pela investigação entre a experiência escolar descrita por Menotti em suas memórias e na ficção $O$ árbitro indicam a forma que assumiu para mascarar a condição do que sentiu durante seus tempos enquanto aluno da instituição. As eventuais críticas ao comportamento dos padres ou mesmo da comida servida no internato são desenvolvidas apenas no conto, com ares ficcionais, ao passo que em suas memórias destaca-se a proteção que recebia do bispo D. Nery por seu bom comportamento.

Ainda assim, o olhar atento para a forma como ele descreveu e assumiu em suas memórias os esforços que empreendeu para garantir proteções do bispo D. Nery demonstra que agiu em prol das imunidades. Antecipando-se a tudo quanto o bispo protetor pudesse precisar, garantiu para si os privilégios de que gostava e marcou um lugar exclusivo, no qual se apoiou durante toda a vida. Como afirmou o próprio Menotti, a amizade estreita com o bispo possibilitou que ele deixasse o internato quando desejasse para ir ao palácio episcopal jantar com D. Nery.

As considerações sobre o que Menotti del Picchia registrou em sua autobiografia sobre o ginásio são, em vários aspectos, diferentes do que ele escreveu na ficção $O$ árbitro. Quando da morte de sua mãe, o pai permitiu que se tornasse aluno externo. No conto, ao saber que seria externo, o rapaz vibrou: "Irra! Era um homem alforriado! Saía do presídio côr de ocre?" (Picchia, 1959, p. 29). Ainda assim, relatou que gostava do cotidiano escolar, do dormitório repleto de camas, da Capela, do riacho e do apito disciplinador do padre.

O pai de Menotti, homem de poucos recursos, não teria como pagar o Ginásio, mas sua proximidade com o bispo garantiu oportunidades aos dois filhos, Menotti e José, que trabalhava como professor. Ali, nos bancos do ginásio, teceram-se as primeiras redes de sociabilidade de Menotti. A formação, seus relacionamentos e a orientação intelectual e religiosa recebida ali compuseram um traço que ofereceu a ele uma experiência diversa da que teria caso não tivesse frequentado o ginásio, como indica em suas memórias: "no colégio estavam ainda Guilherme de Almeida, que viria a ser o Príncipe dos nossos poetas e Plínio Salgado, meu companheiro na jornada modernista, futuro grande escritor e chefe do movimento integralista" (Picchia, 1970, p. 81).

A presença do bispo D. João Batista Nery foi imprescindível para a formação de Menotti. Após a conclusão do ginásio, o bispo o auxiliou a chegar à Faculdade de Direito de 
São Paulo. Apesar da ajuda do bispo, Menotti passava apuros devido à dificuldade do pai de enviar os 100 mil réis necessários à sua manutenção em São Paulo, onde vivia numa pensão.

Com lugar social oposto ao de Menotti del Picchia e privilégios que já se garantiam pelos estratos acessados por sua família, Oswald de Andrade não necessitava de proteções extras, eclesiásticas ou quaisquer outras. Também não percebeu a própria trajetória escolar como imprescindível à formação de suas redes de relações. Em suas memórias, Oswald afirmou de modo evidente que jamais gostou de escolas.

O percurso escolar de Oswald de Andrade se iniciou em 1896, na Escola Modelo Caetano de Campos. Como seus primeiros professores, registrou em suas memórias D. Orminda da Fonseca e D. Isabel Ribeiro. Mais tarde passou para a aula do "seu" Carvalho, que classificou como "ateu danado" (Andrade, 1976, p. 18). Assumidamente avesso às escolas, fazia o que podia para fugir das aulas, sobretudo da ginástica, fingindo doenças e aproveitando-se de outras brechas. A partir de uma fala que o "seu" Carvalho teria feito sobre a existência de Deus, foi imediatamente contar à mãe, esperançoso de sair da escola. Conseguiu o que queria, mas sua felicidade durou pouco.

A família de Oswald, religiosa que era, amedrontou-se diante de um possível professor ateu influenciar a formação do filho e o matriculou no Ginásio Nossa Senhora do Carmo, dos Irmãos Maristas. Menino amimado que sequer brincava na rua, Oswald era levado ao ginásio pelas mãos da empregada da família, e todas as tardes o "seu" Andrade buscava o filho. Mais uma vez o sentimento de Oswald foi hostil ao ambiente escolar, como ele indicou em suas memórias:

Por esse tempo criou-se em São Paulo o Ginásio de Nossa Senhora do Carmo, entregue aos irmãos maristas franceses. Imediatamente aí me matricularam. Nunca fui com os Irmãos Maristas nem com essa primeira experiência ginasial. Os meninos maiores me apalpavam afrontosamente, espiavam-me por cima, na privada. Davam-me cacholetas por causa do lanche enorme que minha mãe preparava. (Andrade, 1976, p. 27)

É possível aproximar o sentimento de antipatia pelos outros meninos a que Oswald se refere ao desconforto que Menotti sentiu com o comportamento dos colegas em $O$ árbitro. Apesar de estarem em instituições católicas destinadas à elite, tanto Menotti del Picchia quanto Oswald de Andrade se assustaram com o comportamento dos outros alunos, dado que se repetiu quando acessaram a Faculdade de Direito de São Paulo e se sentiram humilhados com as brutalidades dos veteranos. 


\section{pro.posıções}

$e$-ISSN 1980-6248

http://dx.doi.org/10.1590/1980-6248-2019-0029

Insatisfeito com o ambiente dos maristas, Oswald novamente convenceu os pais a deixar o ginásio. Segundo registrou em sua autobiografia, preferia estar sozinho "eu me sentia muito melhor e mais feliz do que em meio da canzoada do colégio, nos seus recreios poeirentos e ruidosos, nas suas aulas pálidas e inexistentes" (Andrade, 1976, p. 28). Após essa experiência, seus pais contrataram uma professora particular, mas logo o matricularam no recém-inaugurado Colégio de São Bento, onde permaneceu até o fim dos estudos do ginásio.

A impressão de Oswald sobre o novo colégio foi boa e o menino considerou os monges beneditinos mais simpáticos que os maristas. No Colégio São Bento, foi aluno do professor Gervásio de Araújo. O professor, português exilado, percebeu o talento de Oswald para a literatura, segundo Fonseca (2007), e lhe indicou várias leituras, as quais Oswald atendeu prontamente, passando a frequentar a Casa Garraux, onde conheceu o garoto José Olympio, mais tarde seu editor. O próprio Oswald (1976) afirmou em Um homem sem profissão a importância desse professor em seu desenvolvimento e posterior carreira literária: “o professor Gervásio de Araújo veio decidir a minha vida intelectual. Talvez deva realmente a ele ser escritor.” (p. 43).

Aluno de professores renomados e satisfeito com as leituras indicadas pelo professor Gervásio, Oswald de Andrade parecia estar apreciando o ambiente do São Bento, considerandoo mais sadio que o do Ginásio do Carmo, que considerava promíscuo e sujo. No São Bento, apesar da ameaça de reprovação no quarto ano ginasial, aflorou seus interesses pela literatura e dedicou-se aos estudos: "no colégio, prosseguiram meus triunfos em literatura. Era agora, ao contrário dos primeiros tempos, um dos melhores alunos da turma" (Andrade, 1976, p. 45).

A ameaça de reprovação veio por meio do professor Knuppel, que Oswald afrontava por considerá-lo muito autoritário. O professor ensinava geografia e substituía os demais professores em outras disciplinas. Advogado formado pela Faculdade de Direito do Largo de São Francisco, Knuppel acreditava ser dono de grande saber e caráter. Em determinada ocasião, advogou para o adversário do pai de Oswald numa contenda judicial, de modo que o jovem acreditava ser perseguido pelo professor.

Com a animosidade formada e ameaçado pela iminente reprovação, Oswald estudou as regiões do país em ordem alfabética, seguindo a orientação do professor. No dia do exame, entretanto, Knuppel voltou atrás sobre as questões e chamou os alunos em recuperação para serem examinados por uma banca composta por três professores. Quando chegou a vez de Oswald, o professor ordenou que ele recitasse todos os portos brasileiros de "segunda ordem". 


\section{pro.posıções}

$e$-ISSN 1980-6248

http://dx.doi.org/10.1590/1980-6248-2019-0029

A praxe era para que se recitasse em ordem alfabética, mas, diante da mudança proposta por Knuppel, Oswald passou a recitar a partir do Sul do país. Quando chegou ao Sudeste, inadvertidamente mencionou Rio de Janeiro. O professor, certo da reprovação do aluno provocativo, gritou que o Rio de Janeiro era a capital federal e não poderia ser um porto de "segunda ordem". A resposta de Oswald enfureceu ainda mais o professor de geografia, mas causou gargalhadas gerais e selou seu triunfo:

“-Doutor...

- A capital da República!

— Doutor, perdão, eu desci para ir de barca a Niteróil!” (Andrade, 1976, p. 50)

A reprovação escolar só aconteceu depois. Aos 15 anos, Oswald de Andrade refez a quarta série. Com a conclusão do ginásio em 1908, seguindo a tradição de seu estrato social, ingressou em março de 1909 na Faculdade de Direito de São Paulo. Ao longo de suas memórias, é notável o olhar enviesado que lançou para a Faculdade, levada a cabo apenas por conta dos apelos maternos.

\section{A Faculdade de Direito de São Paulo: ascensão e desapontamento}

A Faculdade de Direito de São Paulo, velha instituição classificada por Miceli (2001) como a instância suprema para a classe política dominante, uniu o dândi Oswald de Andrade e o primo pobre Menotti del Picchia na repulsa à recepção que tiveram por conta do trote imposto pelos veteranos. Para Menotti, as humilhações dos gritos, golpes e uma pancada que lhe quebrou o pince-nez, além da lembrança do paletó do avesso e da farinha na cara, foram traumáticas.

Da mesma forma, Oswald se referiu ao trote violento sofrido na recepção da Faculdade de Direito acusando seus veteranos de imbecilidade e registrando que fazia outra ideia da Faculdade, por conta da tradição e respeito que socialmente se atribuía à instituição. Mesmo dono de personalidade farrista, admitiu sentir-se vexado: 
Fui matricular-me, em março, no primeiro ano da Faculdade de Direito do Largo de São Francisco e aí tive uma das piores decepções de minha mocidade. Os veteranos cercaram a mim e a meu colega Inácio Tamandaré Uchoa aos gritos: — Bicho! Dança, bicho! — E fazendo-nos enfiar as calças por debaixo das meias, nos obrigaram a executar evoluções imbecis. (Andrade, 1976, p. 48)

Para além do trote violento, a crítica de Oswald foi incisiva ao ensino oferecido na Faculdade e à mentalidade de seus professores e alunos, os quais, segundo ele, engrossavam a filosofia do roubo que caracteriza o capitalismo. Menotti del Picchia, ao contrário de Oswald, jamais criticou o ensino da Faculdade de Direito. Sua posição frágil, de outsider no interior de uma instituição suprema da aristocracia paulista, fermentou ainda mais sua ambivalência diante de suas possibilidades. Se, por um lado, Menotti admitiu a importância da instituição em sua trajetória profissional e política, demonstrando inclusive todos os esforços empreendidos para se manter na Faculdade, por outro, sentiu-se pesaroso ao recordar do trote violento e das inúmeras vezes em que foi obrigado a se lembrar de seu lugar social humilde diante de um universo do qual não fazia parte.

Convivendo com a ambivalência desde os bancos escolares, Menotti desenvolveu um comportamento de fachada desde a infância. Quando aluno do Ginásio Diocesano de Pouso Alegre, cometeu um de seus únicos atos de ousadia juvenil. Fundou, com um colega, o jornal $O$ Mandú, no qual escreveu um artigo atacando os padres da instituição. Confrontado pelo monsenhor e diretor do colégio, foi ameaçado de suspensão e recorreu ao irmão, que também o repreendeu:

— Bem feito - replicou êle. Que é que você tinha que meter o bedelho em coisas de um colégio de que você é aluno eu sou professor? Bonito. Que diremos agora ao papai uma vez que, com as quinze faltas da suspensão e as que você já tem, está com o ano perdido? (Picchia, 1970, p. 93).

Com medo de decepcionar o pai e sentindo-se culpado pela situação do irmão, Menotti resolveu encerrar as atividades de O Mandú. Seu irmão intercedeu por ele e procurou o monsenhor, que garantiu que não suspenderia Menotti, afirmando que quis apenas pregar um susto no menino.

Esse episódio indica muito sobre a forma de agir e pensar de Menotti na busca por um lugar tanto na política quanto no movimento modernista e nas esferas sociais mais elevadas. A educação católica recebida por ele arrematou seu pensamento de culpas, assim como o de 


\section{pro.posıções}

$e$-ISSN 1980-6248

http://dx.doi.org/10.1590/1980-6248-2019-0029

Oswald, que, apesar de toda a ousadia e irreverência, sofria com ataques supersticiosos recorrendo a todos os santos que houvesse para confortá-lo.

A religião católica norteou o pensamento e o comportamento de ambos os autores, mas Menotti, talvez por sua condição social, era mais contido. Oswald possivelmente não aceitaria a interferência dos padres em seu trabalho. Em situação semelhante à relatada por Menotti no episódio de $O$ Mandú, Oswald teria apelado à intercessão familiar e provavelmente conseguiria o apoio dos pais, sem jamais se redimir.

\section{As relações travadas com o poder}

Quando estreou no Diário Popular por intermédio do pai, em 1909, Oswald não precisava trabalhar para seu sustento. Os vencimentos de 60 mil réis que recebia pelo trabalho eram gastos em presentes que oferecia aos pais, segundo sua autobiografia. Boaventura (1995) afirma que as tentativas de Oswald na área jornalística canalizaram seu espírito contestador e irreverente. Seu estilo ácido ganhou força no semanário $O$ Pirralho, fundado sob a proteção financeira do pai. Além dessas experiências, foi colunista social no Jornal do Comércio em 1916 e colaborou em diversos veículos de imprensa, como O Jornal e o Correio Paulistano, locais em que teve oportunidade de escrever artigos sobre o movimento cultural de renovação das letras que estava sendo gestado no país, nos quais aproveitava para convocar artistas a repensar sua forma de produção.

A parceria exitosa com Menotti, depois do sucesso de Juca Mulato, os reuniu na fundação da revista ilustrada Papel e Tinta em 1920, veículo no qual pretendiam disseminar suas ideias modernas sobre o novo pensamento nacional, segundo Boaventura (1995). Naquele momento, ambos os autores já demarcavam um posicionamento no interior da classe dirigente que foi a engrenagem mestra e necessária na atração de entusiastas à causa modernista e que culminou na realização da Semana de Arte Moderna dois anos depois.

Menotti del Picchia, contudo, ao contrário de Oswald, sofria reveses para manter-se em São Paulo enquanto aluno da Faculdade de Direito, o que o obrigou a recorrer novamente ao auxílio do bispo D. Nery, que lhe arranjou colocação na secretaria do Seminário da Luz. Seu pai enviava com muita dificuldade 100 mil réis mensais. Em sua autobiografia, Menotti recorda que apenas pela pensão onde dormia pagava 60 mil réis. $O$ valor era o mesmo recebido por Oswald 
na redação do Diário Popular, o qual gastava todo em presentes. Com poucos recursos e sem poder frequentar concertos ou teatros, Menotti afirmou em suas memórias que suas horas vagas eram preenchidas por leituras, em vez de participar das noitadas estudantis.

Feito bacharel, Menotti regressou a Itapira, montou um escritório e passou a se vestir com a mesma audácia que caracterizava o estilo dos dândis, identificada por Bourdieu (1996) em As regras da arte e totalmente incorporada por Oswald de Andrade, conhecido também pela forma como se vestia. Na pequena cidade, Menotti dirigiu o jornal A Cidade de Itapira, sob o comando do Partido Republicano Paulista, ao mesmo tempo em que foi nomeado inspetor escolar. Percebendo que não teria espaço no situacionismo perrepista, optou por fazer oposição aos chefes locais e fundou o jornal O Grito, com o propósito de perturbar as autoridades da pacata cidade. Sem outro partido, o jornal atuava numa espécie de perrepismo rebelde, que posteriormente levou Menotti a colaborar com o Correio Paulistano, jornal que comandava os ditames do Partido.

Menotti afirmou em sua autobiografia que não teve muito sucesso como advogado em Itapira, e que seu jornal não lhe dava rendimentos suficientes, de modo que aceitou a proposta de assumir a chefia da redação do Correio Paulistano, na capital. Ao chegar a São Paulo, entretanto, o lugar já estava preenchido por Antônio Covello, proprietário de A Gaẓta. A coesa rede de sociabilidade perrepista, no entanto, não o desamparou e lhe arranjou a chefia da redação do jornal $A$ Tribuna de Santos, cidade onde passou a residir. Posteriormente, o mesmo grupo o auxiliou a conseguir a vaga de redator-chefe no poderoso Correio Paulistano, o maior órgão de imprensa do Partido Republicano Paulista.

As redes de sociabilidade compostas por Menotti, a despeito de seu lugar social, possibilitaram o encontro e a parceria com Oswald na revista Papel e Tinta e foram responsáveis pela visibilidade que o Correio Paulistano deu ao movimento modernista. A determinação de Menotti e a influência de Oswald, amigo do então governador de São Paulo, o perrepista Washington Luís, foram decisivas para a divulgação dos objetivos do Modernismo. 


\section{pro.posıções}

\section{Considerações finais}

Depois do levantamento de alguns aspectos da vida e dos percursos escolares de Menotti del Picchia e Oswald de Andrade, é necessário estabelecer pontos de aproximação e afastamento entre eles, notadamente na trajetória que seguiram após a Semana de Arte Moderna.

Enquanto para Oswald de Andrade a escola não constituiu fator determinante de ascensão social, de modo que as relações estabelecidas no ambiente escolar funcionaram muito mais como amparo para suas instâncias de sociabilidade e manutenção de capital social, para Menotti del Picchia a oportunidade de escolarização mostrou-se fundamental no sentido de escada social, possibilitando a visibilidade e o capital social necessário para o estabelecimento de redes que o alçaram a um lugar social inédito em seu núcleo familiar. Essa consideração é importante no sentido de explicar que a aproximação dos autores por ocasião da Semana de Arte Moderna só foi possível a Menotti graças a seu percurso escolar, realizado com auxílios de toda ordem, ao contrário de Oswald, cujo espírito irreverente, boas condições econômicas e capital familiar garantiram certa liderança no interior do movimento modernista.

Em comum a ambos, havia a proteção materna, a educação religiosa e a devoção à Igreja Católica. Oswald de Andrade, ainda que não precisasse da assistência da Igreja de que se serviu Menotti, mostrou, diante da piedade, suas fragilidades e ambiguidades, lutando contra as culpas religiosas que o atormentavam. Menotti, filho de imigrantes italianos, teve a mentalidade moldada pelo viés do conservadorismo e da Igreja, e sua ambiguidade se revelou na sensibilidade trazida pela formação artística herdada do pai.

Além disso, a força das relações maternas, canalizadas em figuras especialmente participativas nas escolhas e idiossincrasias da vida de cada um dos autores, mostrou-se vital. Oswald de Andrade deixou claro que a vontade da mãe prevaleceu sobre a sua no episódio da Faculdade de Direito. Incapaz de negar os apelos maternos, após a formatura e com a mãe morta, enveredou pela via jornalística e literária. A análise da trajetória escolar de Menotti mostrou que apenas quando foi obrigado a se separar da mãe percebeu a opressão que a necessidade da escolarização lhe infligia. Ainda assim, e também diante da perda da mãe, orgulhou-se da formação na velha Faculdade.

O curso de Direito, tão criticado por Oswald de Andrade, foi considerado por Menotti como a viga mestra para a sedimentação de seus esforços na busca do capital necessário para 


\section{pro.posıções}

$e$-ISSN 1980-6248

http://dx.doi.org/10.1590/1980-6248-2019-0029

ascensão social, algo que para Oswald de Andrade não fazia sentido, por não estar na base de sua vida política e eventuais sucessos. Mesmo que Oswald de Andrade tivesse contrariado a mãe e escolhido não cursar Direito, suas possibilidades no interior do campo continuariam garantidas. Para a situação de fragilidade social de Menotti del Picchia, contudo, o curso de Direito mostrou outros vieses e o empenho do autor no sentido de conquistar um novo caminho de vida.

Ainda que consideremos ambos os autores como herdeiros das redes de sociabilidade que mobilizaram no interior do movimento modernista, são notáveis as diferenças sociais, culturais e políticas entre eles, sobretudo por força de seu capital político e familiar. Apesar disso, observamos que a trajetória escolar dos autores igualou ou minimizou as desvantagens de Menotti em relação a Oswald. Seu esforço permitiu que se relacionasse com figuras de fora de seu lugar social e ofereceu ao menino de Itapira as primeiras oportunidades de encontro com as instâncias mais importantes da oligarquia paulista, notadamente a Faculdade de Direito de São Paulo e o Partido Republicano Paulista, que o capitalizaram para a liderança do movimento modernista, como afirmou, ao lado de Oswald de Andrade.

Enquanto Menotti se esforçou para cristalizar seu lugar dentro das altas esferas da vida paulista, Oswald de Andrade criticou seu lugar de nascimento com sarcasmo. Para isso, utilizouse do ataque sistemático à instituição mais cara a seu estrato social, a Faculdade de Direito de São Paulo, considerada por ele como atrasada e velha. Segundo Prado (2010), esse posicionamento indica que a época em que foram tecidas as críticas coincide com o projeto restaurador do Brasil, calcado na definição das "bases da nacionalidade", num movimento que se concentrou na retomada do ufanismo pela Independência e pela libertação, cujo único compromisso era garantir a manutenção de interesses oligárquicos.

Fosse como fosse, Oswald de Andrade adotou posicionamentos contra seu estrato social também na política, quando ingressou no Partido Comunista e mostrou boa parte de seu desagrado contra a elite paulista por meio de seus romances. Ao mesmo tempo, Menotti del Picchia deliberadamente cavava oportunidades por meio de pessoas e instituições rechaçadas por Oswald. Pelo fato de não contar com capital herdado, como Oswald, Menotti trabalhou calculadamente no sentido da ascensão social e percebeu que por meio da escolarização seria capaz de acessar estratos diferentes de seu lugar social. 


\section{pro.posıções}

$e$-ISSN 1980-6248

http://dx.doi.org/10.1590/1980-6248-2019-0029

Apesar de distantes pelos lugares sociais e pela geografia, o encontro dos autores no coração do modernismo paulista só foi possível pelo destacamento das redes de sociabilidade tecidas por ambos, que tiveram como base os bancos escolares. Nesse sentido, é seguro afirmar que Menotti soube aproveitar as vantagens oriundas da escolarização, algo que não teve o mesmo peso para Oswald, cujas bases fincadas no capital familiar serviram de pilar para suas escolhas políticas e literárias.

\section{Referências}

Andrade, O. (1976). Um homem sem profissão. Rio de Janeiro: Civilização Brasileira.

Boaventura, M. E. (1995). O salão e a selva: uma biografia ilustrada de Oswald de Andrade. Campinas: Editora Unicamp.

Bourdieu, P. (1996) As regras da arte: gênese e estrutura do campo literário. São Paulo: Companhia das Letras.

Fonseca, M. A. (2007). Oswald de Andrade: biografia. São Paulo: Globo.

Hébrard, J. (2001). O autodidatismo exemplar: como Valentin Jamerey-Duval aprendeu a ler? In R. Chartier (Org.), Práticas da leitura (pp. 35-73). São Paulo: Estação Liberdade.

Martins, W. (2002). A idéia modernista. Rio de Janeiro: Topbooks.

Miceli, S. (2001). Intelectuais à brasileira. São Paulo: Companhia das Letras.

Picchia, M. (1959). O árbitro. São Paulo: Livraria Martins Editora.

Picchia, M. (1970). A longa viagem. São Paulo: Livraria Martins Editora.

Prado, A. A. (2010) Itinerário de uma falsa vanguarda: os dissidentes, a Semana de 22 e o Integralismo. São Paulo: Editora 34

Sevcenko, N. (1992). Orfeu extático na metrópole: São Paulo, sociedade e cultura nos frementes anos 20. São Paulo: Companhia das Letras.

Sirinelli, J.-F. (2003). Os intelectuais. In R. Rémond (Org.), Por uma história politica (2a ed., pp. 231-269). Rio de Janeiro: FGV. 


\section{Referências consultadas}

Melo, L. C. (1954). Dicionário de autores paulistas. São Paulo: Comissão do IV Centenário da cidade de São Paulo.

Picchia, M. (1972). A longa viagem, $2^{a}$ etapa: da Revolução Modernista à Revolução de 1930. São Paulo: Livraria Martins Editora.

\section{Dados da submissão:}

Submetido à avaliação em 08 de abril de 2019; revisado em 19 de setembro de 2019; aceito para publicação em 31 de outubro de 2019.

Autor correspondente: Universidade Estadual de Campinas, Faculdade de Educação, Av. Bertrand Russell, 801, Cidade Universitária, SP, 13083-865, Campinas, SP, Brasil. 